\title{
岩石の亀裂音に関する研究*
}

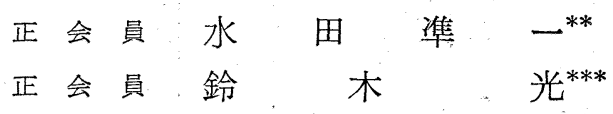

\section{Studies on Crack Noises of Rocks}

Jun-ichi MIZUTA and Ko SUZUKI

\begin{abstract}
Crack noises of rock specimens which are subjected to tensile or compressive stresses wers studied. As the rock specimens, amphibole schist, slate, granite, liparite, porphyrite and tuff were used.

A crystal cartridge and a D. C. pre-amplifier (Fig. 1) were used for recording the noises on a taperecorder. The figures and frequencies of noise waves were investigated on an oscilloscope. To count the noise frequencies, two types of recording appliances were developed; a D. C. motor type counter and an electromagnetic counter (Fig. 3).

Dimensions of the specimens, load applying method, induced crack noise frequencies, etc are summarized on the attached table. Fig. 5-12 are the crack noise count vs. applied load. The crack noises of slate and granite were remarkable. The noise of tuff was poor.
\end{abstract}

\section{1. ま え がき}

岩石は破壊するとき音を発生する。それは角裂を生ず るとき亀裂面に滑り摩擦を生に，その摩擦の際に生ずる 摩擦音であらう。乙たがつて岩石中に発生する免裂音を 捕捉し，これを何らかの形で記録することができれば， あるいは坑内の落盤を予知することができるかも知れな い。このような推測のもと筆者は研究をすすめた。し かしこの問題に関しては, すでに米国の U.S. Bureau of Mines では数年前に研究堂行なつている。米国では 岩石中に Geophone を埋設し, 切羽採掘の進行に伴つ て発生する周囲の岩石の亀裂音を捕捉した。また地層間 に圧縮空気を送入し，人工的に落盤を誘発せしめて，そ の際発生する音波の解析を行なつていた。しかし筆者は それらに関する研究の発表を知らない。

筹者はまず基礎的な研究として，岩石の種類による刍 裂音の波形や周波数相違の有無, 圧縮破壊々引張破壤の 相違などに関し測定を試みるとともに，亀裂音の計測装 置を試作し，破壊に至るまでの波数の計測を行なつたの で，その結果について報告する。

\section{2. 亀裂音探知装置}

岩石の亀裂音は岩石試料を圧縮するか，あるいは加圧 により引張応力を試料内に生ぜしめて，発生せしめる。

供試体は小さく円柱状であるのでピックアップとして

* 昭和 36 年 7 月 22 日受理

** 工博 東京大学教授 鈗山学教室

*** 工博 東京大学助教授 釷山学教室。
クリスタル・カートリッジ（AIWA，CX-309）を用い， これを供試体の表面に軽く接触せしめ使用する。

カートリッジでとらえた振動は試作した直流プリ・ア ンプで増幅し，テープ・コーダに記録せしめるか，ある 、はブラウン管オシロスコープ上佒写する。プリ・ア ンプは低周波用で $80 \mathrm{c} / \mathrm{s}$ より $5,000 \mathrm{c} / \mathrm{s}$ まではほとんど 平坦で $30 \mathrm{c} / \mathrm{s}$ で $-2 \mathrm{db}, 20,000 \mathrm{c} / \mathrm{s}$ で $-3 \mathrm{db}$ であり, 総合利得 $68 \mathrm{db}, \mathrm{S} / \mathrm{N}$ 比 $-54 \mathrm{db}$ である。

プリ・アンプで増幅された振動は, テープ・コーダで さらに増幅され，テープに録音される。振動波形の解析 はブラウン管オシロスコープ上の咉像を撮影して行な い，振動周波数の計数めるいは積算には試作した電磁式 カウンタ, あるいは小型直流モー夕計数器を, あるい注 さらに精密電子管自動計数器を使用した。

電磁式カウンタでは計数能力は10回/secでカウンタを 作動せしめるために注電磁リレーを使用した。電磁リレ 一は確実な作動を行なうためには $30 \mathrm{~mA}$ の電流を要求 するので入力パルスを $6 \mathrm{AU} 6 \mathrm{~L}$ で増幅し, さらに平

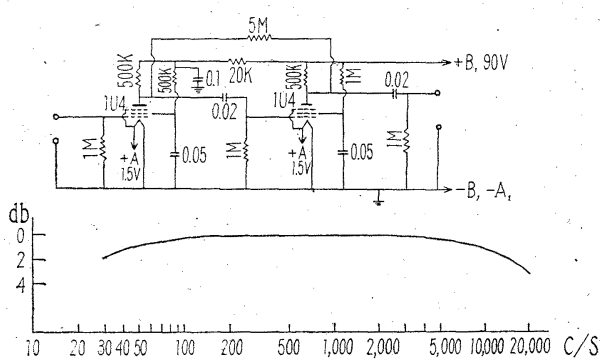

第1図 プリ・アンプの回路と周波数特性 


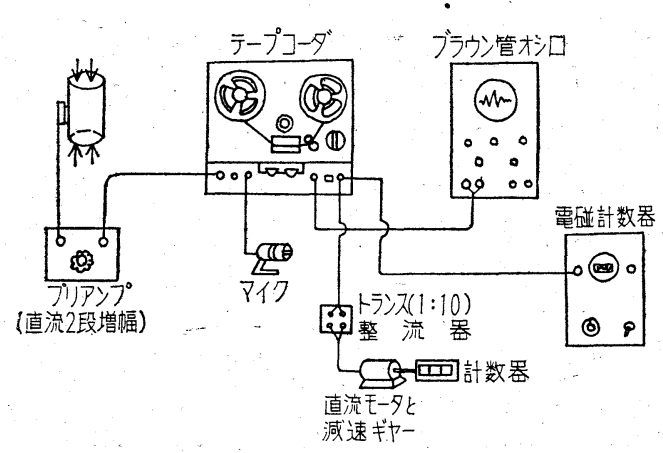

第 2 図 亀裂音測定装置

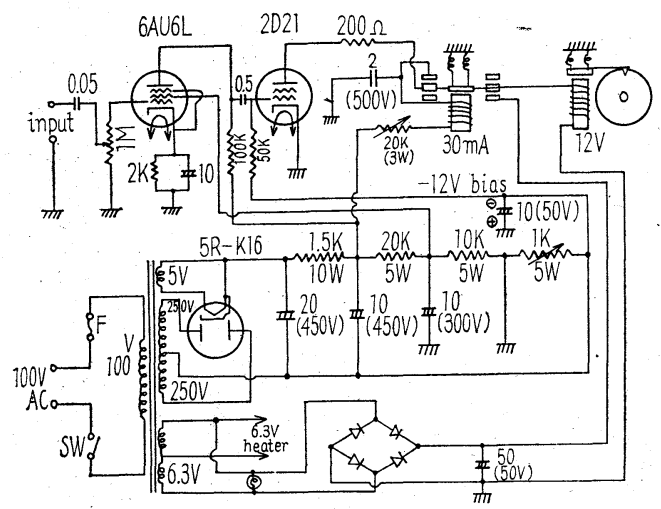

第3図、電磁式計数回路

均陽極電流 $100 \mathrm{~mA}$ の 4 極放電管 $2 \mathrm{D} 21$ を使用して強 陽極電流を得ることとした。この回路によれば10回 $/ \mathrm{sec}$ 以内の計数であれば確実に作動し計数する。

直流モー夕計数器というのは $7.5 \mathrm{~V}, 0.5 \mathrm{~W}$ のマイク ロモー夕に計数器を減速歯車を介して結合したもので, 次式からわかるように直流モータの回転数は電源電圧に 比例し，同時にその作用時間に比例する性質を利用し， 刍裂音のエネルギーを回転数に変換して計数しようと試 みたもので，これは装置が簡単であるばかりでなく，大 カパルスの周期には制限されない。また計数器の機械的 摩擦係数が変化してトルクが変つても，モータの回転数 はいちじるしい変化はない。

いま $E_{t}:$ 外部より加えられる端子電圧

$E_{c}:$ 逆起電力

$I_{a}:$ 運転中の電流

$R_{a}:$ 回転子抵抗

とすれば

$E_{t}=E_{c}+I_{a} \cdot R_{a}$

また $N: 1 \mathrm{~min}$ 間の回転数， $\phi ! 1$ 極からでる磁 束とすれば

$$
E_{c}=K \phi N
$$

(1) と (2) 加ら

$$
N=\frac{E_{c}}{K \phi}=\frac{E_{t}-I_{a} \cdot R_{a}}{K \phi}
$$

$I_{a} \cdot R_{a}$ は $E_{t}$ に比しきわめて小さな值であるし，Kは 常数であるので回転数 $N$ は電源電圧 $\ddot{E}_{t}$ に比例するとい える。

\section{3. 測定結果と考察}

試料には付表に記したように角閃片岩，粘板岩，花崗 岩，流紋岩，玢岩および凝灰岩を使用し，試料を長軸の 方向に圧縮加圧するか，あるいは円柱状試料を直径方向 に加圧して引張破壊まで加区する。加圧は $200 \mathrm{~kg}$ ずつ増 加し，3min 間加圧を一定に保たしめ，その間に発生す る音波をテープ・コーダに記録せしめた。

波形の解析にはブラウン管の横軸を $50 \mathrm{c} / \mathrm{s}$ あるいは $500 \mathrm{c} / \mathrm{s}$ としてテープ上の数個所の音波を撮影し，波形や 振動数を測定した。オシロスコープには単掃引装置を使

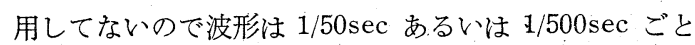
に重なつているものが多いが，解析上にはさしたる不便 はない。第 4 図はこのようにして撮影された亀裂音の波 形の一例を示す。

角閃片岩の引張試験では試料の引張応力が増加しても 亀裂音の周期には大きな変化は見られず，およそ，2,000 $\sim 4,700 \mathrm{c} / \mathrm{s} \cdot$ の振動数を示した。

粘板岩の加圧では低い圧縮応力では低い周波数が，高 応力下では高、周波数の音を発するようである。引張応 力を作用せしめる場合は, 応力の大小化かわらず 4,000 $\sim 4,500 \mathrm{c} / \mathrm{s}$ 程度の周波数が多い。いずれにしても粘板岩 では発生する龟裂音が非常に多い。

花崗岩の圧縮ではおおおむね $2,000 \mathrm{c} / \mathrm{s}$ 前後を示し; 中 には $6,000 \mathrm{c} / \mathrm{s}$ のものも存在したが，圧縮応力の増加に よる周波数の変化浔められず，引䛫によつても同程度 の振動数が多い。

流紋岩の圧縮では応力を増加すれば発生する音波の振 動数も $5,000 \mathrm{c} / \mathrm{s}$ 前後となつて, 応力の低い場合より高 振動数を示すようである。

坋岩の引張では低い応力に対しては $1,000 \mathrm{c} / \mathrm{s}$ 程度を 高応力に対しては $2,150 \mathrm{c} / \mathrm{s}$ を示した。凝灰岩の圧縮で は $2,100 \mathrm{c} / \mathrm{s}$ 程度の振動数が多いようである。

結局以上の試料に引張応力を㗢らかせた場合, 粘板岩 では高振動数の音波を，すなわち高音を発生するが，他 の試料は概敉 $1,000 \sim 2,000 \mathrm{c} / \mathrm{s}$ の振動数を示した。

圧縮応力を作用せしめた場合は，粘板岩や流紋岩では 応力を増加すると亀裂音の振動数も増加する傾向が見受 けられた。

波形について観察すれば，圧縮応力を加えた場合には 粘板岩や花崗岩では正弦波形に近い波形が多く現われて いるのに対し，流紋岩では波形は不規則なものが多く， 引張応力を受けた場合には角閃片岩や轵岩では波形はか なり乱れている。 
ブラウン管オシロスコープにより亀裂音波を解析した 結果, 音波は㧍よそ 1,200 ないし $6,000 \mathrm{c} / \mathrm{s}$ の振動数を 有し，減衰も速かであることがわかつた。そこでつぎに この振動数の計測を試みた。振動波の半波のみを考学る そ，亀裂音をパルスの集合とみなすことができる。その 場合, パルス閒隔を, 実測結果を参照して最高 $6 \mathrm{KPPS}$ 程度とすれば，デカトロンでは計数能力に不安を感ずる が EIT 嵓るいは電子管によれば充分正確に計数できる ことがわかる。

そこでまず，鼌裂音の生ずるエネルギーを比較計数せ しめるモー夕計数法による計数・荷重曲線（試料に加え
た荷重に対する亀裂音計数值を示す曲線）と電子管計数 による同曲線を求め,この両者を比較した。その結果は 第 5 図の例に見られるように，この二つの計数法による 計数值の変化の傾向は, 割合よく類似していることがわ かる。そこで筆者は第 3 図に示した電磁計数器による 1/10sec 以下のパルスを 1 カウントとして計数する電磁 計数法と亀裂音の生ずるエネルギーを比較計数するきー ター計数法によつて計数を行なうこととした。

第 5 12 図はこれら供試体の荷重汶対する龟裂音計数 值を示す。粘板岩や花崗岩では低応力を加えられても嶑 裂音が捕捉され, 破壊直前までの計数は他の供試体の場

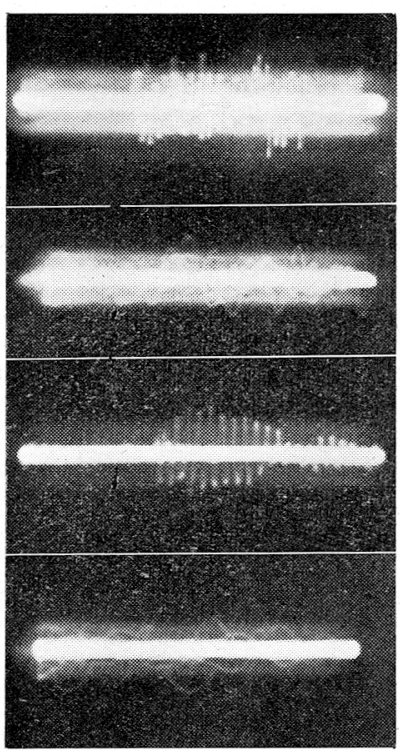

(1)

(2)

(3)

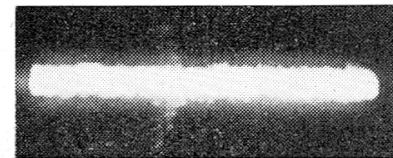

$(5)$

(4)

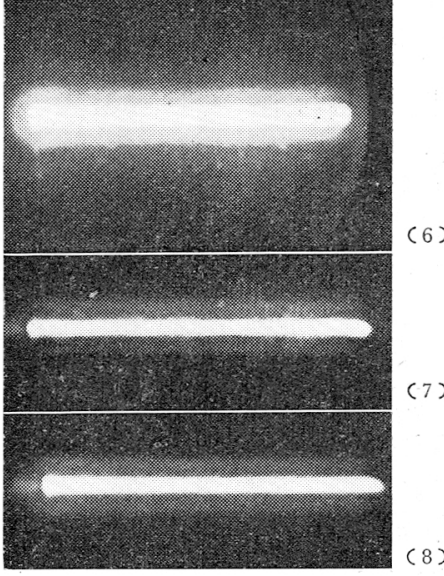

誐料|形状, 寸法| 加圧法

\begin{tabular}{|c|c|c|}
\hline 加 & 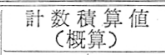 & 急裂 音 \\
\hline & モータ式 電磁式 & の多少 \\
\hline
\end{tabular}

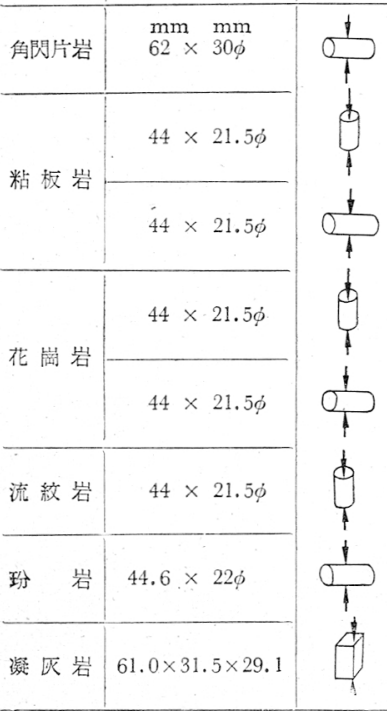

\begin{tabular}{|c|c|c|c|}
\hline $\begin{aligned} 3 t & : 2,670 c / s \quad 4,700 \\
4.8 & : 2,150\end{aligned}$ & 190 & 240 & \\
\hline $\begin{array}{l}3 t: 1,300 \sim 1,480 \\
4: 3,300\end{array}$ & 174 & 940 & 多 \\
\hline $\begin{array}{l}0.2 t: 4,450 \\
1.6: 4,000\end{array}$ & 1,130 & 350 & 多 \\
\hline $\begin{array}{l}1.0 \mathrm{t}: 1,750 \sim 2,825 \\
1.5: 2,200 \sim 6,000 \\
2.5: 2,200 \sim \\
2.5: 2,100 \sim\end{array}$ & 350 & 632 & 多 \\
\hline $1.0 t: 2,100$ & 198 & 17 & \\
\hline $\begin{array}{ll}0.2 \mathrm{t}: & 1,440 \\
0.8 & : 1,800 \\
2.6 & : 5,700 \\
4.0 & : 5,000 \\
\end{array}$ & 120 & 220 & . \\
\hline $\begin{array}{l}0.2 \mathrm{t}: 1,220 \\
2.0=1,210 \\
2.2: 2,150\end{array}$ & 77 & 28 & \\
\hline $0.8 \mathrm{t}: 2,100$ & 112 & 44 & \\
\hline
\end{tabular}

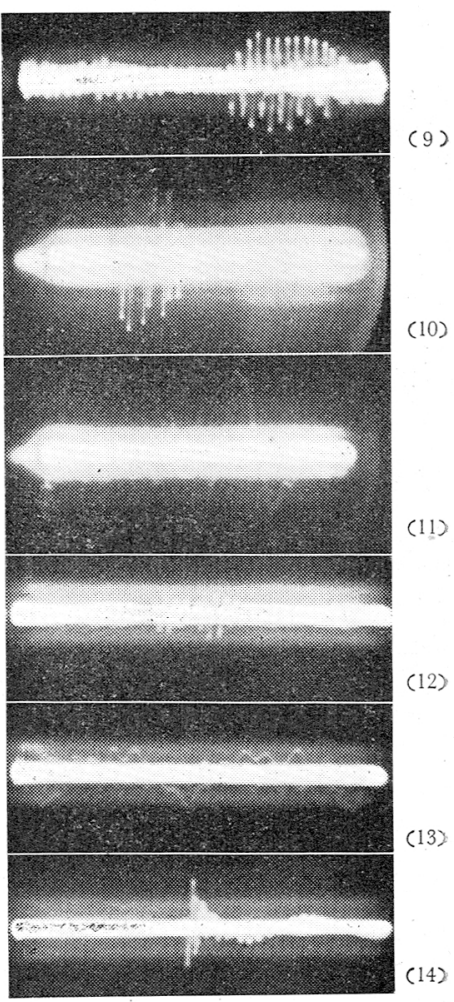

写 真 説 明

(1) 角閃片岩 (引張, $2.8 \mathrm{t} \rightarrow 3.0 \mathrm{t}$ ) $1 / 50 \mathrm{~s}$.

(2) 角閃片岩 (引張, $2.8 \mathrm{t} \rightarrow 3.0 \mathrm{t}$ ) $1 / 500$ s.

(3) 粘板岩 (圧縮, $3 t \rightarrow 3.2 t$ ) 横軸 $1 / 50$ s.

(4) 粘板岩 (玨縮, $3.0 t \rightarrow 3.2 \mathrm{t}$ ) 横刺 $1 / 500 \mathrm{~s}$ 。

(5) 粘板岩 (引張, $1.4 \mathrm{t} \rightarrow 1.6 \mathrm{t}$ ) $1 / 50 \mathrm{~s}$.

(6) 阽板岩 (引張, $1.4 t \rightarrow 1.6 t$ ) $1 / 500 s$.

(7) 花南岩 (圧縮, $2 \mathrm{t} \rightarrow 2.5 \mathrm{t}$ ) 横軸 $1 / 50 \mathrm{~s}$ 。

(8) 花朔岩 (圧縮, $2 \mathrm{t} \rightarrow 2.5 \mathrm{t}$ ) $1 / 500 \mathrm{~s}$.

(9) 花南岩 (引張, $0.8 \mathrm{t} \rightarrow 1.0 \mathrm{t}$ ) $1 / 50 \mathrm{~s}$.

(10) 流紋岩 (压縮, $6 \mathrm{t} \rightarrow 6.5 \mathrm{t}$ ) $1 / 50 \mathrm{~s}$.

(11) 流紋岩 (压縮, 6t $\rightarrow 6$. 5t ) 1/500s.

(12) 玢岩 (引張, $1.8 \mathrm{t} \rightarrow 2.0 \mathrm{t}$ ) $1 / 50 \mathrm{~s}$.

(13) 玢岩 (引涱, $1.8 \mathrm{t} \rightarrow 2.0 \mathrm{t}$ ) 1/500s.

(14) 凝灭岩 (圧縮, $0.4 \mathrm{t} \rightarrow 0.8 \mathrm{t}$ ) 横軸 $1 / 50 \mathrm{~s}$.

第4図 龟 裂音 の 波形 (1) (14) 

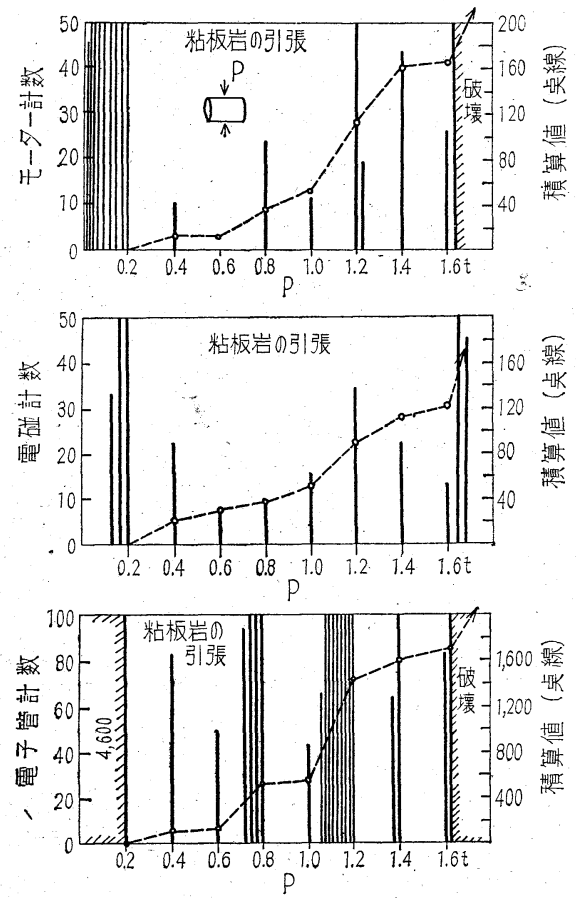

第 5 図引張応力による粘板岩の龟裂音計数

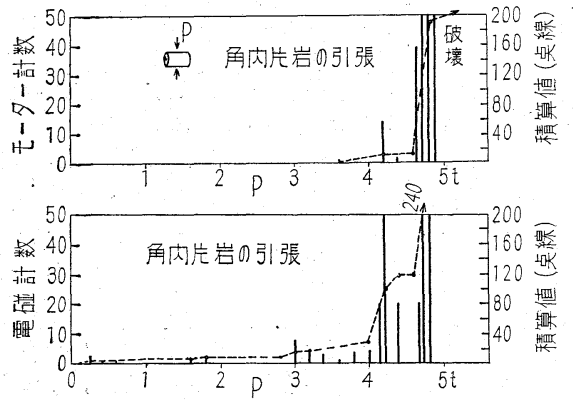

第 6 図引張応力による角閃片岩の亀裂音計数

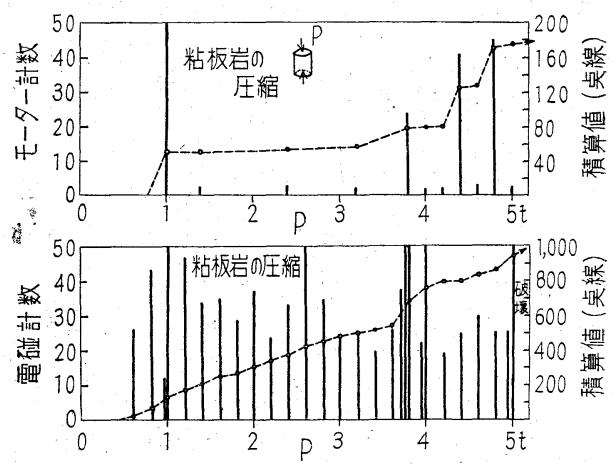

第 7 図 圧縮応力による粘板岩の亀裂音計数
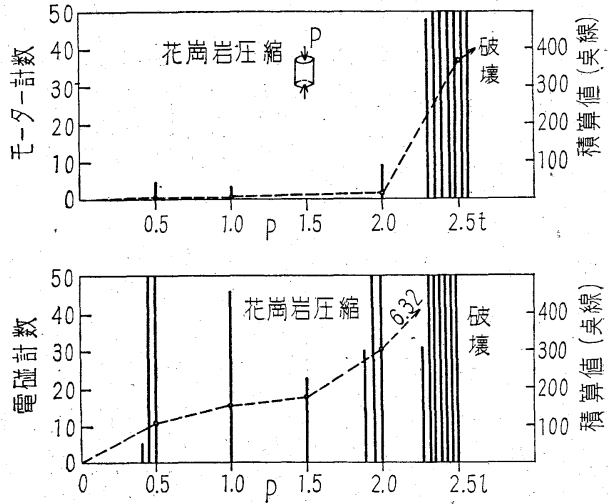

第 8 図 圧縮応力による花崗岩の亀裂音計数

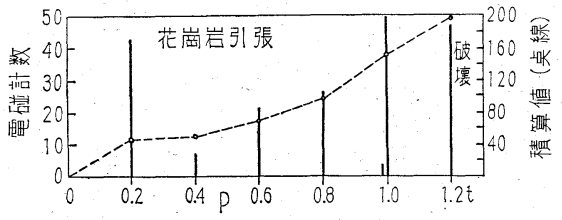

第 9 図 引張応力による花崗岩の亀裂音計数

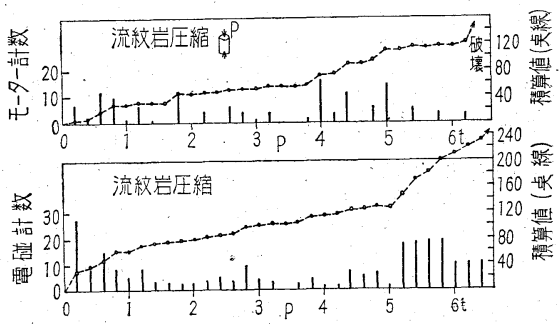

第10図 圧縮応力による流紋岩の亀裂音計数
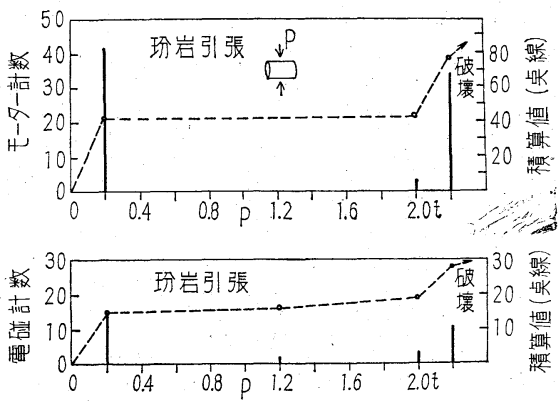

第11図 引張応力による玢岩の亀裂音計数
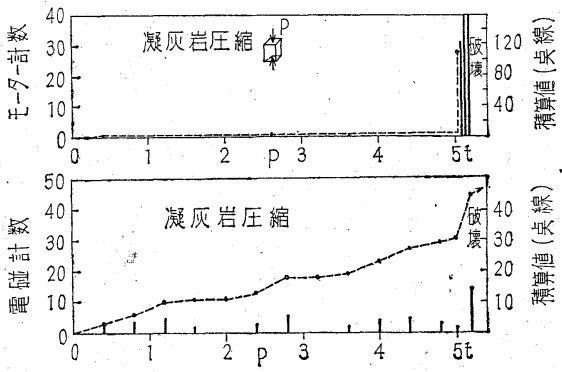

第12図 圧縮応力による凝扊岩の亀裂音計数 
合に比しかなり高いことがわかる。

坋岩が引張応力を受けた場合や凝灰岩に圧縮応力を作 用せしめた場合には発生する龟裂音は非常に少なく, 流 紋岩を加圧せしめる場合は, 低応力に対しても龟裂音を 発生していることが付図よりわかる。

\section{4. 結論}

岩石に発生する亀裂音を捕捉し，これを計数するため に, モータ一計数装置と電磁計数装置を考案した。

モーター計数は亀裂音のエネルギーに比例した計数を 行なうに対し, 電磁計数は微少な単一亀裂音でも捕捉す るが 1/10sec 以下の龟裂音は 1 カウントとして数えるか ら, 微少時間に発生した多数の亀裂音は比較的少数しか カウントされない装置である。この両者による測定結果
によれば，粘板岩や花崗岩は亀裂音を発生しやすく，妢 岩や凝灰岩では亀裂音が少ない。

このような亀裂音は岩石を構成する造岩鉣物の成分, 特に石英質鉱物の多少に影響されることが多いものと考 えられるが, 詳細に関しては今後の研究にまたねばなら ない。

岩石の種類によつては, 比較的低い応力に対しても亀 裂音を発生するので，亀裂音を自動記録せしめることに より，ある程度の落盤予知を行ならことは可能である う。さらに，亀裂音の振動数と応力との間に何らかの関 係を見出すことのできるような岩石に対しては，さらに 精度の高い落盤予報を行ない得るかも知れぬ。

本研究は科学試験研究費の補助を得て行なつたもので ある。

\section{鉄鉱選鉱用としての重液サイクロン}

American Mining Congress 9 シャトル大会で, Cleveland-Cliffs Iron Co. の W. R. van Slyke は 最近の米国に打沙鉄鉱選鉣用の重 液サイクロンの伸展ぶりについて， 大要つぎのように報告している。 鉄鉱石選鉱の手段として重夜サイ クロンを使用する場合，その給鉱の 粒度範囲は，通常上限が $3.2 \sim 6.4$ $\mathrm{mm}$ ，下限が $0.6 \sim 0.2 \mathrm{~mm}(28 \sim 65$ mesh)である。これはしかし各工場 の条件によつて異なる。

小規模の工場では, 重液材として 粉砕した磁鉄鉱 (粒度 +65 mesh 1 $2 \%$ ，-325mesh 50 60\%のむの) を用いるところもある。

一般に上限以上の粒度すなわち， +3.2 または $+6.4 \mathrm{~mm}$ の鉱石は, 在来の静的重液選鉱設備で, 粉砕し たフェロシリコンを重液材として選 鉱される。分離機としてはドラム型 またはスパイラル型のものが，比較 的多く使用されている。

重液サイクロンの処理粒度の䈇囲 を拡大するという傾向も現われてお り，まる工場では $600 \mathrm{~mm} \phi$ サイク ロンで，フェロシリコン重液を用い $-50 \mathrm{~mm}+4.8 \mathrm{~mm}$ の鉱石を好理する 試験が行ねれている。
重液サイうロソの下限以下の粒度 (一28 または一65mesh, +200mesh の範囲) は，通常，ハンフレイ，ス パイラル選鉱機，打よびハイドロサ イザを単独または組合わせた方式で 処理される。

第 1 表は米国ミネンタ地方に拈け る重液サイクロン選鉱工場の数の, 最近10年間に损ける推移を示した統
計である。

第 1 表 米国ミネンタ地方に却ける 重液サイクロソ工場数の推移

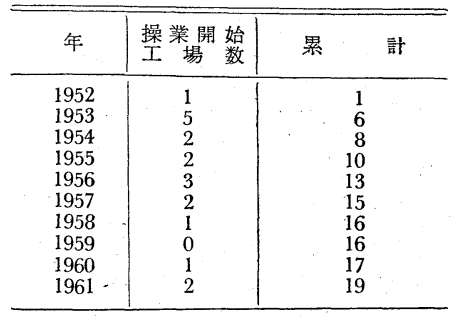

Ore Dressing Progress in Cyclone Plants E \& MJ, Oct, 1961, 128より

\section{銅鉱選鉱における最近の進歩}

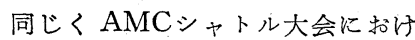
る E. P. Cadwell (American Cy anamid Co.) の報告によれば， 銅鉱の選鉱は最近，機峨的，操業 的，ならびに化学的の 3 方面で, 進 歩を示したという。

まず機械的な面では，粉砕度を向 上し能力を増加するため，大直径の ミルの使用が目立ち, 同時に床面積 節約のため在来の分級機の代りに, サイクロンを採用する傾向が強い， 浮選機は 3 種の型式に競争がし汸ら れて来た。濃縮・沪過の分野では, 大きな変化は見られないが，既設の 機械の処理能力を增加させるため, 沪過助剤と凝結剤を使用することに 対し, 化学工業関係はきわめて熱心
である。

操業上の進歩としては, 選択的抑 制剤とバルク浮選の併用, $\mathrm{pH}$ 調節 装置の精密化，および試薬添加装置 の正確化に向5傾向がある。X線分 析装置の採用は，変動をなくし，実 収率を高水準に保つ効果を示した。 選鉱過程のプログラミングが，やが ては計算機による制御に発展するも のと見られている。

化学的方面では, 清澄用凝結剂と 沪過助剤の使用，それから高品位精 鉱を得るため，精選回路で選択性の 強い試薬を使用することが挙げられ る。

Recent Advances in Copper Concentra, tion, E \& MJ, Oct. 1961, 128〜131 より (今泉) 